\begin{tabular}{lr}
\hline \multicolumn{1}{c}{ D Y N A M I C E C O N O M E T R I C } & M O D E L S \\
DOI: http://dx.doi.org/10.12775/DEM.2013.002 & Vol. 13 (2013) 33-50 \\
\hline $\begin{array}{l}\text { Submitted July 27, 2012 } \\
\text { Accepted April 3, 2013 }\end{array}$ & ISSN \\
\hline
\end{tabular}

\author{
Joanna Olbryś* \\ Asymmetric Impact of Innovations on Volatility \\ in the Case of the US and CEEC-3 Markets: \\ EGARCH Based Approach
}

\begin{abstract}
A b s tra ct. The main goal of this study is to investigate the asymmetric impact of innovations on volatility in the case of the US and three biggest emerging CEEC- 3 markets, using univariate EGARCH approach. We compare empirical results for both the whole sample from Jan 3, 2007 to Dec 30, 2011, and two equal subsamples: the 'down market' period, and the 'up market' period. Pronounced negative asymmetry effects are presented in the case of all markets, and are especially strong in the 'down market' period, which is closely connected with the 2007 US subprime crisis period.
\end{abstract}

K e y w o r d s: volatility, asymmetry effect, down and up market, overlapping information set, univariate EGARCH model.

J E L Classification: C32, C58, G15.

\title{
Introduction
}

The US stock market is found to be the most influential market in the world. The results of many studies support the evidence for US dominance in the international stock markets, and therefore the S\&P 500, the main index of the New York Stock Exchange, is universally accepted as a benchmark index, both in the case of developed and emerging markets research (e.g. Eun, Shim, 1989; Hamao et al., 1990; Koutmos, Booth, 1995; Tse et al., 2003; Syriopoulos, 2007; Lee, Stewart, 2010; Baumöhl, Výrost, 2010;

\footnotetext{
* Correspondence to: Joanna Olbryś, Faculty of Computer Science, Bialystok University of Technology, Wiejska 45A, 15-351 Bialystok, Poland, e-mail: j.olbrys@pb.edu.pl.

(C) 2013 Nicolaus Copernicus University. All rights reserved. http://www.dem.umk.pl/dem
} 
Olbryś, 2013). The recent research evaluates the transmission of the US subprime crisis to both developed and emerging markets. However, the emerging markets responded very strongly to the deteriorating situation in the US financial system and real economy. For example, Dooley's and Hutchson's (2009) regression 'event study' focusing on 15 types of news, indicates that a range of financial and real economic news emanating from the US had statistically and economically large impacts on 14 emerging markets and several news events uniformly moved markets. As a matter of course, there are extremely more 'bad' than 'good' news during the 'crisis' period. Nelson (1991) points out that researchers beginning with Black (1976) found evidence that stock returns are negatively correlated with changes in returns volatility, i.e. volatility tends to rise in response to 'bad news' (excess returns lower than expected) and to fall in response to 'good news' (excess returns higher than expected).

The purpose of this paper is to investigate the asymmetric impact of innovations on volatility in the case of three biggest emerging CEEC $-3^{1}$ markets, and (for comparison) for the US stock market, using univariate EGARCH approach (Nelson, 1991). We try to deal with the 'nonsynchronous trading effect II' by using a 'common trading window' procedure and estimating suitable EGARCH models based on daily open-to-close logarithmic returns for the four major stock market indexes: S\&P 500 (New York), WIG (Warsaw), PX (Prague), and BUX (Budapest). The main goal is to obtain an overlapping information set in the case of the CEEC-3 markets, as we test the impact of common 'bad' and 'good' news. We compare empirical results for both the whole sample from Jan 3, 2007 to Dec 30, 2011 and two equal subsamples: Feb 12, 2007 to Mar 9, 2009 as the 'down market' period and Mar 10, 2009 to Mar 10, 2011 as the 'up market' period. We observe pronounced negative asymmetry effects in the case of all markets, especially in the 'down market' period, which is closely connected with the 2007 US subprime crisis period. To the best of author's knowledge, no such comparative investigation has been undertaken for the US and CEEC-3 stock markets.

As mentioned above, the impact of 'bad' and 'good' news is described in terms of univariate EGARCH models while e.g. Büttner and Hayo (2012) advocate to take into consideration 'actual news' in economic sense (e.g. EMU-related news, news from the ECB, and the like $)^{2}$. They analyze the

\footnotetext{
${ }^{1}$ Three biggest emerging Central and Eastern European Countries (CEEC-3), in order of largest population size are: Poland, the Czech Republic, and Hungary (Büttner, Hayo, 2012).

${ }^{2}$ EMU - European Economic and Monetary Union; ECB - European Central Bank.
} 
impact of news on three financial markets in Poland, the Czech Republic, and Hungary.

The remainder of the paper is organized as follows. Section 1 specifies a methodological background and a brief literature review. First, we stress the validity of the nonsynchronous trading problem. Next, we present the motivation for the choice of 'down market' and 'up market' subperiods. A brief theoretical framework concerning the $\operatorname{EGARCH}(p, q)$ models is also presented. In Section 2, we present the data and an empirical analysis of the asymmetric impact of innovations on volatility in the case of the US developed stock market (as a benchmark market) and the three biggest emerging CEEC -3 markets. Then we discuss the results obtained. Conclusion recalls the main findings and sums them up.

\section{Methodological Background}

\subsection{The Non-Trading Problem}

Some studies distinguish between two nonsynchronous trading effect problems. The first problem, called 'nonsynchronous trading effect I', occurs when we analyze one selected domestic stock market. Stock tradings do not occur in a synchronous manner. Different stocks have different trading frequencies, and even for a single stock the trading intensity varies from hour to hour and from day to day. The actual time of last transaction of the stock varies from day to day. As such we incorrectly assume daily returns as an equally spaced time series with a 24-hour interval (Tsay, 2010, p. 232). The non-trading effect induces potentially serious biases in the moments and comoments of asset returns such as their means, variances, covariances, betas, and autocorrelation and cross-autocorrelation coefficients (e.g. Campbell et al., 1997; Doman, 2011). The second and potentially serious problem, called 'nonsynchronous trading effect II', occurs when we examine the relations between stock markets in various countries. The national stock markets are operating in diverse time zones with different opening and closing times, thereby making return observations nonsynchronous (Eun, Shim, 1989). These differences arise naturally from the fact that trading days in different countries are subject to different national and religious holidays, unexpected events, and so forth (Baumöhl, Výrost, 2010).

This paper investigates the asymmetric impact of innovations on volatility in the case of the three biggest emerging CEEC-3 stock markets, and (for comparison) for the US market. For this reason, we have to deal with the 'nonsynchronous trading effect II'. Many studies attempted various methods 
to deal with the 'nonsynchronous trading effect II'. Some researchers use weekly or monthly data to avoid the non-trading problem. Such solutions, however, may lead to small sample sizes and cannot capture the information transmission in shorter (daily) timeframes (Baumöhl, Výrost, 2010). Other papers present various daily data-matching procedures. For example, Hamao et al. (1990) divide daily close-to-close returns into their close-to-open and open-to-close components. To examine how a nonsynchronous problem would affect the relationships between selected markets, some researchers estimate suitable GARCH-type models (e.g. multivariate EGARCH models) based on the open-to-close returns (cf. Koutmos, Booth, 1995; Tse et al., 2003; Olbrys, 2013). Syriopoulos (2007, p. 46) says: '(...) it would have been ideal to use both the open and close stock market prices, in order to reduce potential non-synchronous trading bias between the US and the European stock markets.' In many studies the following approach, also called a 'common trading window', is very popular: the data are collected for the same dates across the stock markets, removing the data for those dates when any series has a missing value due to no trading (e.g. Eun, Shim, 1989; Booth et al., 1997; Olbrys, 2013).

\subsection{Motivation for The Choice of Subperiods}

In our research, we compare empirical results of asymmetric effects of innovations on volatility in the case of the US and CEEC-3 markets for both the whole sample from Jan 3, 2007 to Dec 30, 2011 and two equal subsamples: Feb 27, 2007 to Mar 9, 2009 as the 'down market' period and Mar 10, 2009 to Mar 10, 2011 as the 'up market' period (each consists of 476 observations). Syczewska (2010) proposed somewhat different subsamples as 'crisis' ('down market') and 'post-crisis' ('up market') periods, but we advocate Feb 27, 2007 as the beginning of the 'down market' period following Dooley and Hutchison (2009), and March 9, 2009 as the end of the 'down market' period because of the global minimum of the S\&P 500 index value in the whole sample achieved on this day. The overall S\&P 500 index fell from 1399.04 (Feb 27, 2007) to 676.53 (March 9, 2009). It lost 51.64\% of previous value during the 'down market' period, which is closely connected with the 2007 US subprime crisis period. Dooley and Hutchison (2009) focus their analysis on the links between the US and a broad range of emerging equity markets over a subprime crisis sample period from Feb 2007 to March 2009, including Poland, Hungary, and the Czech Republic amongst others. Mun and Brooks (2012) extend the Dooley's and Hutchison's analysis to a broader set of individual developed and emerging markets, and also 
extend the whole sample period to Feb 2010 (full 3 years). Frank and Hesse (2009) find that end-February 2007 was a period when early signs of stress began to emerge in global markets prior to the time when the subprime crisis was revealed in mid-2007.

\subsection{The Exponential GARCH Model}

Many researchers documented that stock return volatility tends to rise following 'good' and 'bad' news. This phenomenon was noted both for individual stocks and for market indexes (Braun et al., 1995). Since Nelson (1991) introduced the univariate Exponential Generalized Autoregressive Conditionally Heteroskedastic (EGARCH) model, some papers employ this model to capture the asymmetric effect of innovations on volatility.

Several studies present various applications of univariate and multivariate EGARCH models. In (Koutmos, Booth, 1995) the transmission mechanism of price and volatility spillovers across the New York, Tokyo and London stock markets from three different time zones is investigated, using the EGARCH approach. Jane and Ding (2009) propose the multivariate extension of Nelson's univariate EGARCH model and compare their model with the existing one given by Koutmos and Booth (1995). Booth et al. (1997) provide the evidence on price and volatility spillovers among four Scandinavian (Nordic) stock markets. Bhar (2001) applies an extended bivariate EGARCH model to provide evidence of linkages between the equity market and the index futures market in Australia. Reyes (2001) examines volatility transfers between size-based indexes from the Tokyo Stock Exchange, using a bivariate EGARCH model. Tse et al. (2003) employ a bivariate EGARCH model that allows for both mean and variance spillovers between the US and Polish stock markets. Balaban and Bayar (2005) test the relationship between stock market returns and their forecast volatility derived from the symmetric and asymmetric GARCH-type models in 14 countries. Lee and Stewart (2010) examine asymmetric effects on volatility in the case of the Baltic and Nordic major stock indexes, using both univariate and multivariate EGARCH models. Olbrys (2013) investigates the interdependence of price volatility across the US developed stock market and two emerging Central and Eastern European (CEE) markets in Warsaw and Budapest using a multivariate modified EGARCH model.

As a matter of fact, the asymmetric effects of innovations on volatility for one selected domestic stock market could be well described by the univariate EGARCH model, although it is now widely accepted that a multivariate modeling framework (in the case of the group of markets) leads to 
more relevant empirical models than working with separate univariate models (Bauwens et al., 2006). But it is worth stressing that the multivariate EGARCH model estimation is particularly difficult due to the large number of estimated parameters.

The univariate time series $\left\{R_{t}\right\}$ can be expressed as:

$$
R_{t}=\mu_{t}+\varepsilon_{t},
$$

where:

$\mu_{t}=E\left(R_{t} \mid F_{t-1}\right)$ is the conditional expectation of $R_{t}$ given the past information $F_{t-1}$,

$\varepsilon_{t}$ is the innovation of the series at time $t$.

Nelson's univariate EGARCH(p, q) model can be represented as follows (Tsay, 2010):

$$
\begin{aligned}
& \ln \left(\sigma_{t}^{2}\right)=\alpha_{0}+\frac{1+\beta_{1} B+\cdots+\beta_{q-1} B^{q-1}}{1-\alpha_{1} B-\cdots-\alpha_{p} B^{p}} \cdot g\left(z_{t-1}\right), \\
& \varepsilon_{t}=\sigma_{t} \cdot z_{t} \\
& \varepsilon_{t} \mid F_{t-1} \sim N\left(0, \sigma_{t}\right), z_{t} \sim N(0,1), \\
& g\left(z_{t}\right)=\theta \cdot z_{t}+\gamma \cdot\left[\left|z_{t}\right|-E\left(\left|z_{t}\right|\right)\right]
\end{aligned}
$$

where:

$\sigma_{t}=\operatorname{Var}\left(R_{t} \mid F_{t-1}\right)$ is the conditional variance of $R_{t}$ given the past information $F_{t-1}$,

$\alpha_{0}$ is a constant,

$B$ is the back-shift (or lag) operator such that $B g\left(z_{t}\right)=g\left(z_{t-1}\right)$,

$1+\beta_{1} B+\cdots+\beta_{q-1} B^{q-1}$ and $1-\alpha_{1} B-\cdots-\alpha_{p} B^{p}$ are polynomials with zeros outside the unit circle and have no common factors.

The value of $g\left(z_{t}\right)$ depends on several elements. Nelson (1991) points out that to accommodate the asymmetric relation between stock returns and volatility changes, the value of $g\left(z_{t}\right)$ must be a function of both the magnitude and the sign of $z_{t}$. In Eq. (3), $g\left(z_{t}\right)$ is a linear combination of $z_{t}$ and $\left[\left|z_{t}\right|-E\left(\left|z_{t}\right|\right)\right]$ with coefficients $\theta$ and $\gamma$. The term in the bracket measures the magnitude effects and the coefficient $\gamma$ relates lagged standardized innovations to volatility in a symmetric way. The term $\theta \cdot z_{t}$ measures the sign 
effects and the coefficient $\theta$ relates standardized shocks to volatility in an asymmetric style. $\left\{g\left(z_{t}\right)\right\}_{t=-\infty, \infty}$ is an i.i.d. random sequence with mean zero (Jane, Ding, 2009). For $\theta<0$ the future conditional variances will increase proportionally more as a result of a negative shock than for a positive shock of the same absolute magnitude (Bollerslev, Mikkelsen, 1996). Both $z_{t}$ and $\left[\left|z_{t}\right|-E\left(\left|z_{t}\right|\right)\right]$ are zero mean i.i.d. random sequences with continuous distributions. The asymmetry of $g\left(z_{t}\right)$ can be easily seen by rewriting it as:

$$
g\left(z_{t}\right)=\left\{\begin{array}{l}
(\theta+\gamma) \cdot z_{t}-\gamma \cdot E\left(\left|z_{t}\right|\right) \text { if } z_{t} \geq 0, \\
(\theta-\gamma) \cdot z_{t}-\gamma \cdot E\left(\left|z_{t}\right|\right) \text { if } z_{t}<0 .
\end{array}\right.
$$

Since $\operatorname{EGARCH}(p, q)=\operatorname{EGARCH}(1,1)$ is a simple case, Eq. (2) becomes:

$$
\left(1-\alpha_{1} B\right) \cdot \ln \left(\sigma_{t}^{2}\right)=\left(1-\alpha_{1} B\right) \cdot \alpha_{0}+g\left(z_{t-1}\right),
$$

Eq. (5) can be rewritten (subscript of $\alpha_{1}$ is omitted) and then:

$$
\ln \left(\sigma_{t}^{2}\right)=\alpha_{0}^{*}+\alpha \cdot \ln \left(\sigma_{t-1}^{2}\right)+g\left(z_{t-1}\right),
$$

where $\alpha_{0}^{*}=$ const.

The parameter $\alpha$ in Eq. (6) determines the influence of the past conditional volatility on the current conditional volatility. For the conditional volatility process to be stationary, $|\alpha|<1$ is required. The persistence of volatility may be also quantified by examination of the half-life $(H L)$ defined by:

$$
H L=\frac{\ln (0.5)}{\ln |\alpha|}
$$

which measures the time period required for the innovations to be reduced to one-half of their original size.

An additional advantage of the EGARCH model is that no parameter restrictions are required to insure positive variances at all times (Fiszeder, 2009).

Let $R_{i, t}=100 \cdot \ln \frac{C_{i, t}}{O_{i, t}}$ be the open-to-close percentage logarithmic return at time $t$ for market $i(i=1,2,3,4$, where $1=$ New York, $2=$ Warsaw, 
$3=$ Prague, and $4=$ Budapest $).$ Then, the univariate $\operatorname{AR}(1)-\operatorname{EGARCH}(1,1)$ model for market $i$ may be written as follows:

$$
\begin{aligned}
& R_{i, t}=\varphi_{i, 0}+\varphi_{i} R_{i, t-1}+\varepsilon_{i, t}, \\
& \ln \left(\sigma_{i, t}^{2}\right)=\alpha_{i, 0}^{*}+\alpha_{i} \cdot \ln \left(\sigma_{i, t-1}^{2}\right)+\theta_{i} \cdot z_{t}+\gamma_{i} \cdot\left[\left|z_{t}\right|-E\left(\left|z_{t}\right|\right)\right] .
\end{aligned}
$$

\section{Empirical Results}

\subsection{Data Description and Preliminary Statistics}

The raw data consists of daily opening and closing prices of major stock market indexes for New York (S\&P 500 index), Warsaw (WIG index), Prague (PX index), and Budapest (BUX index). As mentioned in Introduction, the main goal was to obtain the overlapping information set in the case of the CEEC-3 markets, as we tested the impact of common 'bad' and 'good' news. We used the 'common trading window' procedure and removed the data for those dates when any series has a missing value due to no trading. Thus all the data are collected for the same dates across the four markets and finally there are 1181 observations for each series for the period beginning Jan 3, 2007 and ending Dec 30, 2011. Since CEEC-3 countries are geographically close, the trading hours for the markets are about the same. Trading at the WSE (WIG index) starts at 9:00 a.m. and finishes at 5:40 p.m. CET (Central European Time). Prague (PX index) trades from 9:00 a.m. to 4:30 p.m., Budapest (BUX index) trades from 9:00 a.m. to 5:00 p.m. while the NYSE (S\&P 500 index) trades from 3:30 p.m. to 10:00 p.m. CET ${ }^{3}$. The trading overlap between the CEEC-3 and New York markets is approximately equal to one and a half hours, i.e. late trading in Warsaw, Prague or Budapest corresponds to early trading in New York. We advocate to use daily open-to-close logarithmic returns, as these returns inform about the situation on a given stock market between the opening and closing time.

We compute daily close-to-close, close-to-open, and open-to-close logarithmic returns for the four stock indexes. Following Hamao et al. (1990), we divide daily close-to-close $(\mathrm{C}-\mathrm{C})$ logarithmic returns into their close-to-open $(\mathrm{C}-\mathrm{O})$ and open-to-close $(\mathrm{O}-\mathrm{C})$ components:

$$
C-C=\ln \frac{C_{t}}{C_{t-1}}, C-O=\ln \frac{O_{t}}{C_{t-1}}, O-C=\ln \frac{C_{t}}{O_{t}},
$$

\footnotetext{
${ }^{3}$ Sources: http://www.standardandpoors.com/ ; http://www.gpw.pl// $;$ http://www.pse.cz/ ; http://bse.hu/.
}

Dynamic ECONOMETRIC Models 13 (2013) 33-50 
we obtain consequently that a daily close-to-close logarithmic return can be expressed as:

$$
\ln \frac{O_{t}}{C_{t-1}}+\ln \frac{C_{t}}{O_{t}}=\ln \frac{O_{t}}{C_{t-1}} \cdot \frac{C_{t}}{O_{t}}=\ln \frac{C_{t}}{C_{t-1}}
$$

where $C_{t}$ and $C_{t-1}$ are the closing prices of days $t$ and $(t-1)$, respectively, and $O_{t}$ is the opening price of day $t$.

Note that on a given day $t$, because the CEEC-3 markets open before the US market, daytime information set from the US market would have an influence on the CEEC-3 markets on the next day. An information set can be seen in broad terms as the set of all information relevant for pricing an asset at a given time (Baumöhl, Výrost, 2010). Therefore, the information on the opening and closing values of the CEEC-3 and US stock markets indexes does not belong to the same information set, however, the information set for the CEEC-3 markets is overlapping.

Table 1 reports summarized statistics for the close-to-close, close-toopen, and open-to-close logarithmic returns for four stock indexes: S\&P 500, WIG, PX, and BUX, as well as statistics testing for normality and interdependence. The sample means are not statistically different from zero. The measures for skewness and excess kurtosis show that all return series are negatively skewed and highly leptokurtic with respect to the normal distribution. Likewise, the Doornik-Hansen (2008) test rejects normality for each of the return series at the 5 per cent level of significance. The Ljung-Box (1978) statistic at the lag $q \approx \ln T$, where $T$ is the number of data points (Tsay, 2010, p. 33), calculated for both the return and the squared return series, indicates the presence of significant linear and non-linear dependencies, respectively, except the WIG O-C and PX O-C series. The linear dependences may be due to the 'nonsynchronous trading effect I' of the stocks that make up each index (e.g. Campbell et al., 1997). The non-linear dependences may be due to the autoregressive conditional heteroskedasticity (e.g. Nelson, 1991; Koutmos, Booth, 1995; Booth et al., 1997). All calculations were done using Gretl 1.9.11 (Adkins, 2012). 
Table 1. Summarized statistics for the close-to-close, close-to-open, and open-toclose logarithmic returns for four stock indexes: S\&P 500, WIG, PX, and BUX

\begin{tabular}{|c|c|c|c|c|c|c|c|c|}
\hline & $\begin{array}{c}\text { Number of } \\
\text { obs. }\end{array}$ & Mean & $\begin{array}{l}\text { Standard } \\
\text { deviation }\end{array}$ & Skewness & $\begin{array}{l}\text { Excess } \\
\text { kurtosis }\end{array}$ & $\begin{array}{c}\text { Doornik- } \\
\text { Hansen test }\end{array}$ & $\mathrm{LB}(7)$ & $\operatorname{LB}^{2}(7)$ \\
\hline $\begin{array}{c}\text { S\&P } 500 \\
\text { C-C }\end{array}$ & 1260 & $-9 \cdot 10^{-5}$ & 0.017 & $-0.25^{\star}$ & $6.53^{\star}$ & $\begin{array}{c}729.71^{*} \\
{[0.0]}\end{array}$ & $34.42^{*}$ & $742.66^{*}$ \\
\hline $\begin{array}{c}\text { S\&P } 500 \\
\text { C-O }\end{array}$ & 1260 & $-9 \cdot 10^{-5}$ & 0.002 & $-0.28^{*}$ & $7.29^{*}$ & $\begin{array}{c}836.62^{\star} \\
{[0.0]}\end{array}$ & $28.13^{*}$ & $173.47^{\star}$ \\
\hline $\begin{array}{c}\text { S\&P } 500 \\
\text { O-C }\end{array}$ & 1260 & $4 \cdot 10^{-7}$ & 0.016 & $-0.31^{*}$ & $6.62^{*}$ & $\begin{array}{c}724.33^{*} \\
{[0.0]}\end{array}$ & $33.84^{*}$ & $740.99 *$ \\
\hline $\begin{array}{l}\text { WIG } \\
\text { C-C }\end{array}$ & 1256 & $-2 \cdot 10^{-4}$ & 0.015 & $-0.37^{\star}$ & $2.63^{\star}$ & $\begin{array}{c}174.69^{*} \\
{[0.0]}\end{array}$ & $17.57^{\star}$ & $268.82^{\star}$ \\
\hline $\begin{array}{l}\text { WIG } \\
\mathrm{C}-\mathrm{O}\end{array}$ & 1256 & $6 \cdot 10^{-4}$ & 0.009 & $-0.76^{*}$ & $5.38^{*}$ & $\begin{array}{c}370.39^{\star} \\
{[0.0]}\end{array}$ & $27.44^{*}$ & $552.66^{*}$ \\
\hline $\begin{array}{l}\text { WIG } \\
\text { O-C }\end{array}$ & 1256 & $-8 \cdot 10^{-4}$ & 0.013 & $-0.29^{\star}$ & $2.83^{*}$ & $\begin{array}{c}209.38^{\star} \\
{[0.0]}\end{array}$ & 7.27 & 255.28 * \\
\hline $\begin{array}{l}\text { PX } \\
C-C\end{array}$ & 1258 & $-4 \cdot 10^{-4}$ & 0.018 & $-0.57^{*}$ & $12.66^{*}$ & $\begin{array}{c}1541.46^{*} \\
{[0.0]}\end{array}$ & $31.08^{*}$ & 778.58 * \\
\hline $\begin{array}{l}\mathrm{PX} \\
\mathrm{C}-\mathrm{O}\end{array}$ & 1258 & $4 \cdot 10^{-4}$ & 0.013 & $-0.71^{*}$ & $13.35^{\star}$ & $\begin{array}{c}1545.51^{*} \\
{[0.0]}\end{array}$ & $28.21^{*}$ & $609.05^{\star}$ \\
\hline $\begin{array}{l}\text { PX } \\
\text { O-C }\end{array}$ & 1258 & $-8 \cdot 10^{-4}$ & 0.013 & $-1.34^{\star}$ & $12.00^{*}$ & $\begin{array}{c}731.53^{\star} \\
{[0.0]}\end{array}$ & 9.44 & $199.15^{\star}$ \\
\hline $\begin{array}{l}\text { BUX } \\
\mathrm{C}-\mathrm{C}\end{array}$ & 1254 & $-3 \cdot 10^{-4}$ & 0.020 & $-0.02^{*}$ & $5.67^{*}$ & $\begin{array}{c}624.96^{*} \\
{[0.0]}\end{array}$ & $52.16^{\star}$ & $584.76^{*}$ \\
\hline $\begin{array}{l}\text { BUX } \\
\mathrm{C}-\mathrm{O}\end{array}$ & 1254 & $7 \cdot 10^{-4}$ & 0.011 & $-0.29^{*}$ & $9.61^{*}$ & $\begin{array}{c}1190.26^{*} \\
{[0.0]}\end{array}$ & $49.11^{*}$ & $869.96 *$ \\
\hline $\begin{array}{l}\text { BUX } \\
O-C\end{array}$ & 1254 & $-1 \cdot 10^{-3}$ & 0.017 & $-0.47^{\star}$ & $3.81^{*}$ & $\begin{array}{c}288.20^{\star} \\
{[0.0]}\end{array}$ & $19.77^{\star}$ & $320.37^{\star}$ \\
\hline
\end{tabular}

Note: the table is based on all sample observations during the period Jan 2, 2007-Dec 31, 2011. C-C, $\mathrm{C}-\mathrm{O}$, and $\mathrm{O}-\mathrm{C}$ stand for close-to-close, close-to-open, and open-to-close logarithmic returns for four stock indexes (S\&P 500, WIG, PX, BUX), respectively. * denotes significance at the 5 per cent level. The test statistic for skewness and excess kurtosis is the conventional $t$-statistic. The Doornik-Hansen test (2008) has a $\chi^{2}$ distribution if the null hypothesis of normality is true. Numbers in brackets are $p$-values. $\operatorname{LB}(q)$ and $\operatorname{LB}^{2}(q)$ are the Ljung-Box (1978) statistics for returns and squared returns, respectively, distributed as $\chi^{2}(q), \mathrm{q} \approx \ln T$, where $T$ is the number of data points (Tsay, 2010). The $\chi^{2}(7)$ critical value is 14.07 $(5 \%)$.

\subsection{Asymmetric Impact of Innovations on Volatility}

To examine asymmetric effects between positive and negative index return innovations, we first estimate the univariate $\operatorname{AR}(1)-\operatorname{EGARCH}(1,1)$ models of the four stock indexes: S\&P 500, WIG, PX, and BUX, in the whole sample period from Jan 3, 2007 to Dec 30, 2011. The robust QML 
(Bollerslev, Wooldridge, 1992) estimates of the parameters of the model (8) are presented in Table $2^{4}$.

Table 2. Results from the AR(1)-EGARCH $(1,1)$ models of the four stock indexes: S\&P 500, WIG, PX, and BUX. Full sample period from Jan 3, 2007 to Dec 30, 2011 (1181 daily open-to-close percentage logarithmic returns)

\begin{tabular}{|c|c|c|c|c|}
\hline & $\begin{array}{c}\text { New York } \\
(\mathrm{i}=1)\end{array}$ & $\begin{array}{l}\text { Warsaw } \\
(\mathrm{i}=2)\end{array}$ & $\begin{array}{c}\text { Prague } \\
(i=3)\end{array}$ & $\begin{array}{c}\text { Budapest } \\
(\mathrm{i}=4)\end{array}$ \\
\hline \multicolumn{5}{|c|}{ Conditional mean equation } \\
\hline$\phi_{i, 0}$ & $0.024(0.033)$ & $-0.060^{\star}(0.029)$ & $-0.052^{\star}(0.026)$ & $-0.092^{\star}(0.039)$ \\
\hline$\phi_{i}$ & $-0.084^{\star}(0.027)$ & $-0.022(0.026)$ & $-0.055(0.030)$ & $-0.056(0.031)$ \\
\hline \multicolumn{5}{|c|}{ Conditional variance equation } \\
\hline$\alpha_{i, 0}^{*}$ & $-0.101^{*}(0.020)$ & $-0.108^{*}(0.028)$ & $-0.166^{\star}(0.034)$ & $-0.117^{\star}(0.030)$ \\
\hline$\alpha_{i}$ & $0.978 *(0.007)$ & $0.983^{*}(0.007)$ & $0.977^{\star}(0.011)$ & $0.979 *(0.010)$ \\
\hline$\theta_{i}$ & $-0.141 *(0.020)$ & $-0.083^{\star}(0.019)$ & $-0.047^{\star}(0.020)$ & $-0.034(0.020)$ \\
\hline$\gamma_{i}$ & $0.142^{*}(0.026)$ & $0.144^{*}(0.037)$ & $0.227^{\star}(0.049)$ & $0.179 *(0.044)$ \\
\hline \multicolumn{5}{|c|}{ Conditional density parameters } \\
\hline$v_{i}$ & $7.515^{\star}(1.713)$ & $10.923^{\star}(2.989)$ & $5.743^{\star}(0.846)$ & $6.538^{\star}(1.178)$ \\
\hline$\lambda_{i}$ & $-0.227^{*}(0.041)$ & $-0.019(0.033)$ & $-0.078^{*}(0.039)$ & $-0.007(0.043)$ \\
\hline \multicolumn{5}{|c|}{ Asymmetry effect for market i } \\
\hline$\delta_{i}=\theta_{i} / \gamma_{i}$ & -0.99 & -0.58 & -0.21 & -0.19 \\
\hline Half-life $(H L)$ & 31.16 & 40.43 & 29.79 & 32.66 \\
\hline Log-likelihood & -1872.80 & -1833.79 & -1735.00 & -2145.68 \\
\hline $\mathrm{BIC}$ & 3802.19 & 3724.16 & 3526.59 & 4347.92 \\
\hline AIC & 3761.60 & 3683.58 & 3486.00 & 4307.64 \\
\hline $\operatorname{LB}(20)$ & $11.42[0.93]$ & $14.23[0.82]$ & $7.97[0.99]$ & $16.80[0.67]$ \\
\hline $\mathrm{LB}^{2}(20)$ & $25.76[0.17]$ & $14.39[0.81]$ & $16.60[0.68]$ & $13.89[0.84]$ \\
\hline
\end{tabular}

Note: the table is based on all sample observations during the period Jan 3, 2007-Dec 30, 2011; * denotes significance at the 5 per cent level; the heteroskedastic consistent standard errors are in parentheses; the variance-covariance matrix of the estimated parameters is based on the QML algorithm; the distribution for the innovations is supposed to be skewed $\mathrm{t} ; v$ and $\lambda$ are conditional density parameters (Lucchetti, Balietti S, 2011, p. 3); the asymmetry coefficient is defined in the text; the half-life is defined in the text and represents the time it takes for the shock to reduce its impact by one-half; BIC and AIC are the information criterions; $\mathrm{LB}(20)$ and $\mathrm{LB}^{2}(20)$ denotes the Ljung-Box (1978) statistics for standardized innovations and squared standardized innovations, respectively (Baillie, Bollerslev, 1990); numbers in brackets are $p$-values.

\footnotetext{
${ }^{4}$ In the case of all periods analyzed, the choice of an appropriate version of the EGARCH model was conducted based on the BIC and AIC information criterions, and distributions for the innovations were supposed to be normal, t-Student, or skewed $t$. As it turned out, the univariate $\mathrm{AR}(1)-\mathrm{EGARCH}(1,1)$ models with skewed $\mathrm{t}$ as the distribution for the innovations are the most adequate. Due to the space restrictions, details and calculations are available upon request.
} 
For model checking, the Ljung-Box statistics $\mathrm{LB}(20)$ for the standardized innovation process, and $\operatorname{LB}^{2}(20)$ for the squared standardized innovations were applied (Baillie, Bollerslev, 1990). The evidence is that there is no serial correlation or conditional heteroskedasticity in the standardized innovations of the fitted models. The estimated AR(1)-EGARCH $(1,1)$ models are adequate (Tsay, 2010, p. 146).

Several results presented in Table 2 are worth special notice. The autoregressive coefficients $\varphi_{i}$ are negative, and this coefficient is statistically significant only for the New York market. The conditional variance is a function of past conditional variances and past innovations. The relevant coefficients $\alpha_{i}, \theta_{i}$, and $\gamma_{i}$ are statistically significant at the 5 per cent level in the case of all models (except $\theta_{4}$ ). In addition, all of the $\gamma_{i}$ coefficients are positive. For positive $\gamma_{i}$, if $\delta_{i}=\theta_{i} / \gamma_{i}<0$, then negative innovations have a higher impact on volatility than positive innovations; if $\delta_{i}=0$ ( $\theta_{i}=0$ and $\gamma_{i}>0$ ), then the magnitude terms raises (lowers) volatility when the magnitude of market movements is large (small); if $0<\delta_{i}<1$, then positive innovations would increase volatility but negative innovations decrease volatility. These pronounced negative asymmetry effects are present in Table 2. For New York, Warsaw, Prague, and Budapest, negative innovations increase volatility considerably more than positive innovations. Our findings suggest that the four stock markets are more sensitive to 'bad' than 'good' news.

The persistence of volatility may be interpreted by using the half-life concept (7), which measures the time it takes for an innovation to reduce its impact by one half. Numerically, the $H L$ coefficients for the New York, Warsaw, Prague, and Budapest indexes are equal to: $31.16,40.43,29.79$, and 32.66 days, respectively. It is worth stressing that the half-life coefficients are surprisingly high, however Scheicher (2001, p. 37) documents half-life coefficients for the CTX, HTX, and PTX indexes, which are equal to: $16.39,1.95$, and $\infty$ (!) days. For example, Bhar (2001) documents half-life coefficients equal to 2.63 and 3.86 days for two Australian spot and futures markets, respectively.

Figure 1. presents time plots of conditional variances from the univariate AR(1)-EGARCH $(1,1)$ models for the S\&P 500, WIG, PX, and BUX index-

\footnotetext{
${ }^{5}$ CTX, HTX, and PTX are the Czech, Hungarian, and Polish Traded Indexes, which are computed by the Central European Clearing Houses and Exchange (CECE) in Vienna (Scheicher (2001, p. 28).
} 
es, in the whole sample period from Jan 3, 2007 to Dec 30, 2011. The global financial crisis was reflected evidently in all stock exchanges (cf. Figure 1).
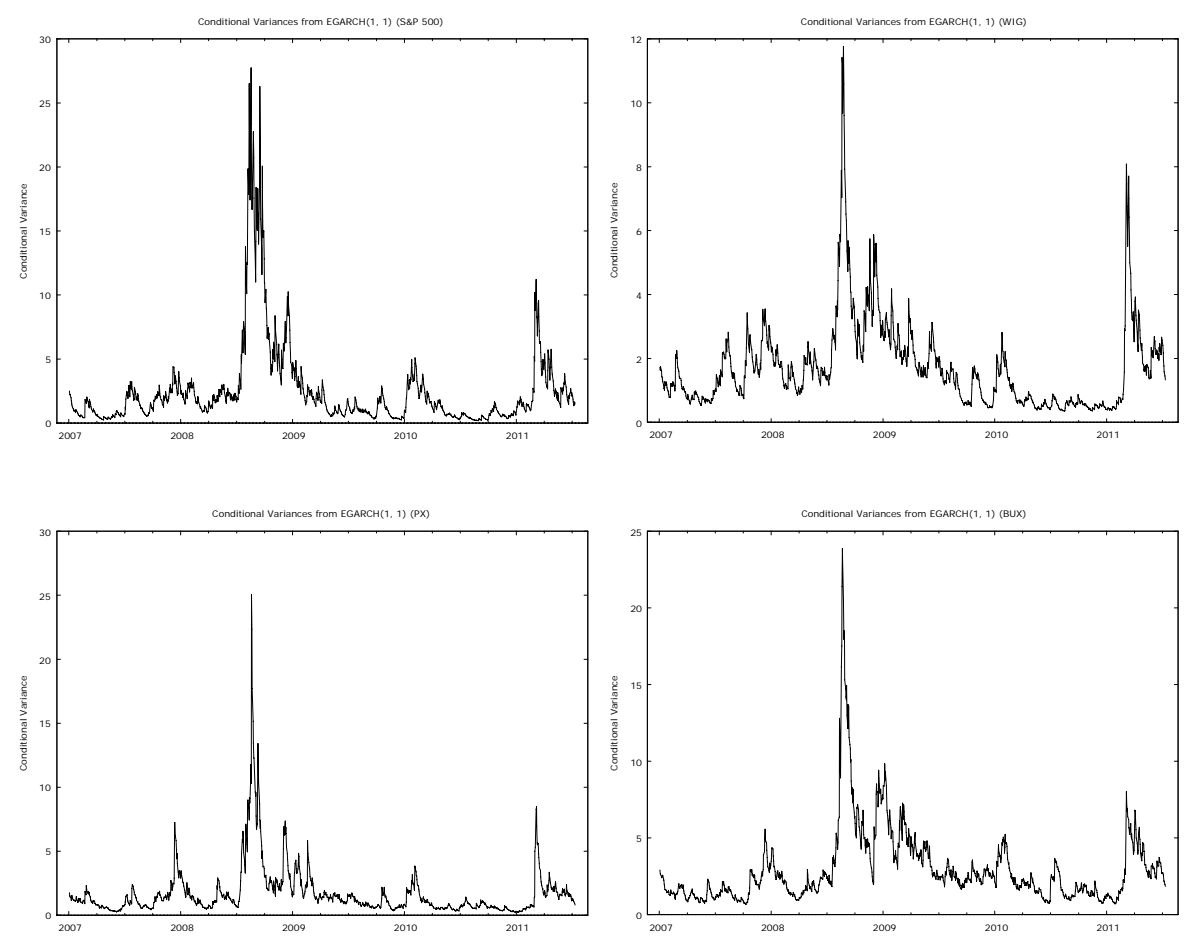

Figure 1. Conditional variances from the univariate $\operatorname{AR}(1)-\operatorname{EGARCH}(1,1)$ models for the S\&P 500, WIG, PX, and BUX indexes, in the whole sample period from Jan 3, 2007 to Dec 30, 2011 (Table 2).

Tables $3 \mathrm{a}-3 \mathrm{~b}$ present further analysis, including details about results from the AR(1)-EGARCH(1, 1) models of the four stock indexes in:

- the 'down market' period from Feb 27, 2007 to Mar 9, 2009 (Table 3a),

- the 'up market' period from March 10, 2009 to Mar 10, 2011 (Table 3b). 
Table 3a. Results from the AR(1)-EGARCH $(1,1)$ models of the four stock indexes: S\&P 500, WIG, PX, and BUX. The 'down market' period from Feb 27, 2007 to Mar 9, 2009 (476 daily open-to-close percentage logarithmic returns)

\begin{tabular}{|c|c|c|c|c|}
\hline & $\begin{array}{c}\text { New York } \\
(\mathrm{i}=1)\end{array}$ & $\begin{array}{l}\text { Warsaw } \\
(\mathrm{i}=2)\end{array}$ & $\begin{array}{c}\text { Prague } \\
(\mathrm{i}=3)\end{array}$ & $\begin{array}{c}\text { Budapest } \\
(\mathrm{i}=4)\end{array}$ \\
\hline \multicolumn{5}{|c|}{ Conditional mean equation } \\
\hline$\phi_{i, 0}$ & $-0.086(0.060)$ & $-0.139^{\star}(0.056)$ & $-0.056(0.047)$ & $-0.119(0.061)$ \\
\hline$\phi_{i}$ & $-0.141^{*}(0.041)$ & $-0.058(0.043)$ & $-0.063(0.048)$ & $0.030(0.047)$ \\
\hline \multicolumn{5}{|c|}{ Conditional variance equation } \\
\hline$\alpha_{i, 0}^{*}$ & $-0.069^{\star}(0.028)$ & $-0.061(0.034)$ & $-0.131^{*}(0.052)$ & $-0.162^{*}(0.058)$ \\
\hline$\alpha_{i}$ & $0.965^{\star}(0.009)$ & $0.970 *(0.011)$ & $0.960 *(0.013)$ & $0.972^{\star}(0.016)$ \\
\hline$\theta_{i}$ & $-0.182^{\star}(0.035)$ & $-0.127^{\star}(0.029)$ & $-0.136^{\star}(0.043)$ & $-0.048^{\star}(0.038)$ \\
\hline$\gamma_{i}$ & $0.117^{*}(0.034)$ & $0.098^{*}(0.040)$ & $0.188^{*}(0.068)$ & $0.250 *(0.082)$ \\
\hline \multicolumn{5}{|c|}{ Conditional density parameters } \\
\hline$v_{i}$ & $17.061(14.100)$ & $15.610(10.273)$ & $6.484^{\star}(1.710)$ & $6.026^{\star}(1.651)$ \\
\hline$\lambda_{i}$ & $-0.253^{\star}(0.059)$ & $0.017(0.062)$ & $-0.126(0.080)$ & $-0.025(0.059)$ \\
\hline \multicolumn{5}{|c|}{ Asymmetry effect for market i } \\
\hline$\delta_{i}=\theta_{i} / \gamma_{i}$ & -1.56 & -1.30 & -0.72 & -0.19 \\
\hline Half-life $(H L)$ & 19.46 & 22.76 & 16.98 & 24.41 \\
\hline Log-likelihood & -841.76 & -806.98 & -763.88 & -858.78 \\
\hline $\mathrm{BIC}$ & 1732.82 & 1663.26 & 1577.06 & 1766.86 \\
\hline AIC & 1699.52 & 1629.96 & 1543.75 & 1733.55 \\
\hline $\mathrm{LB}(20)$ & $15.35[0.76]$ & $23.40[0.27]$ & $11.69[0.93]$ & $23.47[0.27]$ \\
\hline $\mathrm{LB}^{2}(20)$ & $27.21[0.13]$ & $13.60[0.85]$ & $17.09[0.65]$ & $12.19[0.91]$ \\
\hline
\end{tabular}

Note: the table is based on observations during the 'down market' period February 27, 2007-March 9, 2009; * denotes significance at the 5 per cent level; the heteroskedastic consistent standard errors are in parentheses; the variance-covariance matrix of the estimated parameters is based on the QML algorithm; the distribution for the innovations is supposed to be skewed $t ; v$ and $\lambda$ are conditional density parameters (Lucchetti, Balietti S, 2011, p. 3); the asymmetry coefficient is defined in the text; the half-life is defined in the text and represents the time it takes for the shock to reduce its impact by one-half; BIC and AIC are the information criterions; $\mathrm{LB}(20)$ and $\mathrm{LB}^{2}(20)$ denotes the Ljung-Box (1978) statistics for standardized innovations and squared standardized innovations, respectively (Baillie, Bollerslev, 1990); numbers in brackets are $p$-values.

The results in Tables $3 \mathrm{a}-3 \mathrm{~b}$ clearly show that the asymmetric effects between positive and negative index return innovations are especially strong in the 'down market' period (cf. Table 3a). All of the $\gamma_{i}$ coefficients are significantly positive, all of the $\theta_{i}$ coefficients are significantly negative, and then suitable $\delta_{i}=\theta_{i} / \gamma_{i}$ coefficients are negative, therefore we conclude that negative innovations have a higher impact on the volatility than positive innovations. It is worthwhile to note that the asymmetry effect is extremely strong 
in the case of the New York $\left(\delta_{1}=-1.56\right)$ and Warsaw $\left(\delta_{2}=-1.30\right)$ markets. Suitable half-life coefficients for the New York, Warsaw, Prague, and Budapest indexes are equal to: 19.46, 22.76, 16.98, and 24.41 days, and are numerically comparable.

Table 3b. Results from the AR(1)-EGARCH $(1,1)$ models of the four stock indexes: S\&P 500, WIG, PX, and BUX. The 'up market' period from Mar 10, 2009 to Mar 10, 2011 (476 daily open-to-close percentage logarithmic returns)

\begin{tabular}{|c|c|c|c|c|}
\hline & $\begin{array}{c}\text { New York } \\
(i=1)\end{array}$ & $\begin{array}{c}\text { Warsaw } \\
(\mathrm{i}=2)\end{array}$ & $\begin{array}{c}\text { Prague } \\
(i=3)\end{array}$ & $\begin{array}{c}\text { Budapest } \\
(\mathrm{i}=4)\end{array}$ \\
\hline \multicolumn{5}{|c|}{ Conditional mean equation } \\
\hline$\phi_{i, 0}$ & $0.101^{*}(0.000)$ & $-0.0003(0.042)$ & $-0.065(0.043)$ & $-0.028(0.067)$ \\
\hline$\phi_{i}$ & $-0.065^{\star}(0.000)$ & $0.016(0.049)$ & $-0.010(0.039)$ & $-0.071(0.052)$ \\
\hline \multicolumn{5}{|c|}{ Conditional variance equation } \\
\hline$\alpha_{i, 0}^{*}$ & $-0.159 *(0.034)$ & $-0.129 *(0.054)$ & $-0.146^{*}(0.068)$ & $-0.074(0.049)$ \\
\hline$\alpha_{i}$ & $0.971^{\star}(0.016)$ & $0.984^{\star}(0.013)$ & $0.962^{\star}(0.032)$ & $0.989^{\star}(0.015)$ \\
\hline$\theta_{i}$ & $-0.112^{\star}(0.041)$ & $-0.037(0.034)$ & $0.026(0.036)$ & $-0.006(0.025)$ \\
\hline$\gamma_{i}$ & $0.216^{\star}(0.048)$ & $0.162^{\star}(0.071)$ & $0.193^{\star}(0.096)$ & $0.105(0.075)$ \\
\hline \multicolumn{5}{|c|}{ Conditional density parameters } \\
\hline$v_{i}$ & $5.439 *(1.183)$ & $9.942^{\star}(3.997)$ & $5.412^{\star}(1.215)$ & $10.093^{\star}(3.981)$ \\
\hline$\lambda_{i}$ & $-0.148 *(0.051)$ & $0.057(0.070)$ & $-0.021(0.064)$ & $0.045(0.066)$ \\
\hline \multicolumn{5}{|c|}{ Asymmetry effect for market i } \\
\hline$\delta_{i}=\theta_{i} / \gamma_{i}$ & -0.52 & -0.23 & 0.13 & -0.06 \\
\hline Half-life $(H L)$ & 23.55 & 42.97 & 17.89 & 62.67 \\
\hline Log-likelihood & -674.60 & -678.30 & -649.60 & -892.64 \\
\hline $\mathrm{BIC}$ & 1398.51 & 1405.90 & 1348.51 & 1834.60 \\
\hline AIC & 1365.21 & 1372.59 & 1315.20 & 1801.29 \\
\hline $\mathrm{LB}(20)$ & $19.77[0.47]$ & $21.10[0.39]$ & $11.03[0.95]$ & $26.96[0.14]$ \\
\hline $\operatorname{LB}^{2}(20)$ & $23.61[0.26]$ & $10.76[0.95]$ & $19.01[0.52]$ & $11.27[0.94]$ \\
\hline
\end{tabular}

Note: the table is based on observations during the 'up market' period March 10, 2009-March 10, 2011; * denotes significance at the 5 per cent level; the heteroskedastic consistent standard errors are in parentheses; the variance-covariance matrix of the estimated parameters is based on the QML algorithm; the distribution for the innovations is supposed to be skewed $t ; v$ and $\lambda$ are conditional density parameters (Lucchetti, Balietti S, 2011, p. 3); the asymmetry coefficient is defined in the text; the half-life is defined in the text and represents the time it takes for the shock to reduce its impact by one-half; BIC and AIC are the information criterions; $\operatorname{LB}(20)$ and $\operatorname{LB}^{2}(20)$ denotes the Ljung-Box (1978) statistics for standardized innovations and squared standardized innovations, respectively (Baillie, Bollerslev, 1990); numbers in brackets are $p$-values.

As for the 'up market' period the evidence is that the estimated univariate EGARCH models are qualitatively rather poor. Most of the parameters are not statistically significant at the 5 per cent level. Essentially, the research provides evidence that the four markets are not homogeneous 
regarding the asymmetric impact of innovations on volatility in the 'up market' period, as well as the half-life coefficient size. The asymmetric effects between positive and negative index return innovations are present in the case of three markets (i.e. New York, Warsaw, and Budapest). Suitable halflife coefficients for the New York, Warsaw, Prague, and Budapest indexes are equal to: $23.55,42.97,17.89$, and 62.67 days, and are substantially higher compared those in the 'down market' period. This evidence confirms that the four stock markets are more sensitive to 'bad' than 'good' news.

\section{Conclusions}

Our research provides evidence for pronounced asymmetric impact of innovations on volatility in the case of the US and CEEC- 3 markets, especially in the 'down market' period (Feb 27, 2007-March 9, 2009). We conclude that negative innovations have a higher impact on volatility than positive innovations. Our findings suggest that the four stock markets are more sensitive to 'bad' than 'good' news.

A possible and interesting direction for further investigation would be an asymmetry effects investigation in the case of the US and CEEC-3 markets, in terms of other asymmetric GARCH-type models (cf. Engle, 2000; Bauwens et al., 2006).

\section{References}

Adkins, L. C. (2012), Using Gretl for Principles of Econometrics, 4th Edition, Version 1.03.

Balaban, E., Bayar, A. (2005), Stock Returns and Volatility: Empirical Evidence from Fourteen Countries, Applied Economics Letters, 12, 603-611, DOI: http://dx.doi.org/10.1080/13504850500120607.

Baillie, R. T., Bollerslev, T. (1990), A Multivariate Generalized ARCH Approach to Modeling Risk Premia in Forward Foreign Exchange Rate Markets, Journal of International Money and Finance, 9, 309-324, DOI: http://dx.doi.org/10.1016/0261-5606(90)90012-O.

Baumöhl, E., Výrost, T. (2010), Stock Market Integration: Granger Causality Testing with Respect to Nonsynchronous Trading Effects, Finance a Uver: Czech Journal of Economics and Finance, 60(5), 414-425.

Bauwens, L, Laurent, S., Rombouts, J.V.K. (2006), Multivariate GARCH Models: A Survey, Journal of Applied Econometrics, 21, 79-109, DOI: http://dx.doi.org/10.1002/jae.842.

Bhar, R. (2001), Return and Volatility Dynamics in the Spot and Futures Markets in Australia: an Intervention Analysis in a Bivariate EGARCH-X Framework, Journal of Futures Markets, 21, 833-850, DOI: http://dx.doi.org/10.1002/fut.1903.

Black, F. (1976), Studies of Stock Market Volatility Changes, 1976 Proceedings of the American Statistical Association, Business and Economic Statistics Section, 177-181.

Dynamic ECONOMETRIC Models 13 (2013) 33-50 
Bollerslev, T., Mikkelsen, H. O. (1996), Modeling and Pricing Long Memory in Stock Market Volatility, Journal of Econometrics, 73, 151-184, DOI: http://dx.doi.org/10.1016/0304-4076(95)01736-4.

Bollerslev, T., Wooldridge, J. M. (1992), Quasi-Maximum Likelihood Estimation and Inference in Dynamic Models with Time-Varying Covariances, Econometric Reviews, 11, 143-179, DOI: http://dx.doi.org/10.1080/07474939208800229.

Booth, G. G., Martikainen T., Tse Y. (1997), Price and Volatility Spillovers in Scandinavian Stock Markets, Journal of Banking \& Finance, 21, 811-823, DOI: http://dx.doi.org/10.1016/S0378-4266(97)00006-X.

Braun, P. A., Nelson, D. B., Sunier, A. M. (1995), Good News, Bad News, Volatility, and Betas, The Journal of Finance, 50(5), 1575-1603, DOI: http://dx.doi.org/10.2307/2329327.

Büttner, D., Hayo, B. (2012), EMU-Related News and Financial Markets in the Czech Republic, Hungary and Poland, Applied Economics, 44(31), 4037-4053, DOI: http://dx.doi.org/10.1080/00036846.2011.587775.

Campbell J.Y., Lo A.W., MacKinlay A.C. (1997), The Econometrics of Financial Markets, Princeton University Press, New Jersey.

Doman, M. (2011), Mikrostruktura giełd papierów wartościowych (Stock Exchange Microstructure), Poznan University of Economics Press.

Dooley, M., Hutchison, M. (2009), Transmission of the U.S. Subprime Crisis to Emerging Markets: Evidence on the Decoupling - Recoupling Hypothesis, Journal of International Money and Finance, 28, 1331-1349, DOI: http://dx.doi.org/10.1016/j.jimonfin.2009.08.004.

Doornik, J. A., Hansen, H. (2008), An Omnibus Test for Univariate and Multivariate Normality, Oxford Bulletin of Economics and Statistics, 70, 927-939, DOI: http://dx.doi.org/10.1111/j.1468-0084.2008.00537.x.

Engle, R. F. (ed.) (2000), ARCH. Selected Readings, Oxford University Press.

Eun, C. S., Shim, S. (1989), International Transmission of Stock Market Movements, The Journal of Financial and Quantitative Analysis, 24(2), 241-256, DOI: http://dx.doi.org/10.2307/2330774.

Fiszeder, P. (2009), Modele klasy GARCH w empirycznych badaniach finansowych (The Class of GARCH Models in Empirical Finance Research), Torun, Nicolaus Copernicus University Press.

Frank, N., Hesse, H. (2009), Financial Spillovers to Emerging Markets during the Global Financial Crisis, Finance a Uver: Czech Journal of Economics and Finance, 59(6), 507-521.

Hamao, Y., Masulis, R. W., Ng, V. (1990), Correlations in Price Changes and Volatility across International Stock Markets, Review of Financial Studies, 3(2), 281-307, DOI: http://dx.doi.org/10.1093/rfs/3.2.281.

Jane, T-D, Ding, C. G. (2009), On the Multivariate EGARCH Model, Applied Economics Letters, 16, 1757-1761, DOI: http://dx.doi.org/10.1080/13504850701604383.

Koutmos, G., Booth, G. G. (1995), Asymmetric Volatility Transmission in International Stock Markets, Journal of International Money and Finance, 14(6), 747-762, DOI: http://dx.doi.org/10.1016/0261-5606(95)00031-3.

Lee, J., Stewart, G. (2010), Asymmetric Volatility and Volatility Spillovers in Baltic and Nordic Stock Markets, European Journal of Economics, Finance and Administrative Sciences, 25, 136-143.

Ljung, G., Box, G. E. P. (1978), On a Measure of Lack of Fit in Time Series Models, Biometrika, 66, 67-72.

DYNAMIC ECONOMETRIC MODELS 13 (2013) 33-50 
Lucchetti, K., Balietti, S., (2011), The gig package, Version 2.2.

Mun, M., Brooks, R. (2012), The Roles of News and Volatility in Stock Market Correlations during the Global Financial Crisis, Emerging Markets Review, 13, 1-7, DOI: http://dx.doi.org/10.1016/j.ememar.2011.09.001.

Nelson, D. B. (1991), Conditional Heteroskedasticity in Asset Returns: A New Approach, Econometrica, 59, 347-370, DOI: http://dx.doi.org/10.2307/2938260.

Olbryś, J. (2013), Price and Volatility Spillovers in the Case of Stock Markets Located in Different Time Zones, Emerging Markets Finance \& Trade, 49(2), 145-157, DOI: http://dx.doi.org/10.2753/REE1540-496X4902S208.

Reyes, M .G. (2001), Asymmetric Volatility Spillover in the Tokyo Stock Exchange, Journal of Economics and Finance, 25(2), 206-213, DOI: http://dx.doi.org/10.1007/BF02744523.

Scheicher, M. (2001), The Comovements of Stock Markets in Hungary, Poland and the Czech Republic, International Journal of Finance and Economics, 6, 27-39, DOI: http://dx.doi.org/10.1002/ijfe.141.

Syczewska, E. M. (2010), Changes of Exchange Rate Behavior During and After Crisis, Quantitative Methods in Economics, WULS Press, 11(1), 145-157.

Syriopoulos, T. (2007), Dynamic Linkages between Emerging European and Developed Stock Markets: Has the EMU any Impact?, International Review of Financial Analysis, 16, 41-60, DOI: http://dx.doi.org/10.1016/j.irfa.2005.02.003.

Tsay, R. S. (2010), Analysis of Financial Time Series, John Wiley, New York.

Tse, Y., Wu, C., Young, A. (2003), Asymmetric Information Transmission between a Transition Economy and the U.S. Market: Evidence from the Warsaw Stock Exchange, Global Finance Journal, 14, 319-332,

DOI: http://dx.doi.org/10.1016/j.gfj.2003.09.001.

\section{Asymetryczny wpływ dodatnich i ujemnych stóp zwrotu na zmienność w przypadku rynków Stanów Zjednoczonych, Polski, Czech i Węgier: podejście oparte na modelu EGARCH}

$\mathrm{Z}$ a r y s t r e ś c i. Artykuł przedstawia badania dokumentujące asymetryczny wpływ dodatnich i ujemnych stóp zwrotu na zmienność w przypadku rynków Stanów Zjednoczonych, Polski, Czech i Węgier, z wykorzystaniem jednorównaniowych wykładniczych modeli EGARCH (Nelson, 1991). Porównawcze analizy empiryczne dotyczą okresu styczeń 2007-grudzień 2011 oraz dwóch jednakowo licznych podokresów: spadków (27.02.2007-9.03.2009) i wzrostów (10.03.2009-10.03.2011). Stwierdzono wyraźny efekt asymetrii na wszystkich badanych rynkach, szczególnie silny w wyróżnionym okresie spadkowym, wyznaczonym w oparciu o zmiany wartości indeksu S\&P500 i ściśle związanym z okresem kryzysu finansowego w Stanach Zjednoczonych.

S łow a kluc zow e: zmienność, efekt asymetrii, okresy spadków i wzrostów, wspólny zbiór informacji, model EGARCH.

\section{Acknowledgements}

I would like to thank prof. Evzen Kocenda and prof. Jan Hanousek for providing me with the data on Prague Stock Exchange Index. GACR grant No. 403/11/0020 as a source of the data is acknowledged. I am especially indebted to anonymous referees for their valuable comments and suggestions which greatly improved the paper.

Dynamic EConometric Models 13 (2013) 33-50 